\title{
PUBLIC SECTOR OR PRIVATE SECTOR EMPLOYMENT? PERSPECTIVES OF STUDENTS OF A PRIVATE COLLEGE IN PENANG
}

\section{Woo Kuan Heong ${ }^{1}$ and Teng Kee Tuan ${ }^{2 *}$}

\author{
${ }^{1}$ School of Social Sciences, Universiti Sains Malaysia, Pulau Pinang, Malaysia \\ ${ }^{2}$ Faculty of Accountancy, Finance and Business, Economics \& Corporate \\ Administration Division, Tunku Abdul Rahman University College, Penang \\ Branch Campus, Malaysia \\ "Corresponding author: tengkt@tarc.edu.my
}

Published online: 24 April 2019

To cite this article: Woo, K.H. and Teng, K.T. 2019. Public sector or private sector employment? Perspectives of students of a private college in Penang. Kajian Malaysia 37(1): 1-25. https://doi. org $/ 10.21315 / \mathrm{km} 2019.37 .1 .1$

To link to this article: https://doi.org/10.21315/km2019.37.1.1

\begin{abstract}
This study investigates factors affecting private college graduating students seeking public employment after graduation using a cross-sectional survey that involved 1,290 final-year students of a private college in Malaysia. Findings suggest that job characteristics, and some background and personal characteristics are significant determinants of respondents seeking government jobs. The study also found that the perception of discrimination against minority groups in public sector recruitment and promotion practices is prevalent among respondents. This study provides useful information to policymakers and employers in devising appropriate measures to attract talents. It is also useful to career counsellors in providing career advice to students to develop their career plans.
\end{abstract}

Keywords: sectoral preference, college student, public employment, job characteristics, attractiveness discrimination

\section{INTRODUCTION}

The choice of career is important, especially for graduating students, who are firsttime job-seekers. When a job is chosen, a person has actually also made a decision that would affect the way s/he allocates time for her/his working and non-working hours. However, many graduating students do not begin to seriously consider and explore the possibilities of careers until after graduation. Discussions with college 
seniors showed that there is a disconnection between student life and launching a successful career (Fertig 2016). In addition to its impact on the individual, the choice of career also has important consequences for the society in which the choice is made (Vroom 1967). A career is an iterative and ongoing process that involves reproduction and transformation of structures (Cohen, Duberley and Mallon 2004). Therefore, young people's career decisions would influence the competition for human resources in various fields, altering professional and vocational training programmes, transforming the structure of the labour market, impacting the productivity of society, and affecting government policy, among others. It is the consequences for society that underlie this study to investigate the public sector's ability to attract graduate job seekers.

Almost all aspects of our social life are affected by government policies. Considering the discretionary power that civil servants possess in decision-making and resource allocation, recruiting public personnel is more than an economic issue of labour employment but also a social issue of equality, a policy issue of inclusiveness, and a political issue of legitimacy of a government. A unique feature of Malaysia is its plural society. In 2016, the Malaysian population was $30,949,962$, which was made up of $50.1 \%$ Malays, $11.8 \%$ bumiputeras (indigenous), 22.6\% Chinese, 6.7\% Indians, and 8.9\% others (Index Mundi 2016). However, in December 2014, the total number of civil servants stood at 1,606,463 with a high number of Malays (78.8\%), a fair number of bumiputeras (11.2\%), but only 5.2\% Chinese, $4.1 \%$ Indians, and $0.7 \%$ others (FMT Reporters 2015). ${ }^{1,2}$ Comparing the country's demographic and civil service racial breakdown suggests the increasingly mono-ethnic nature of the Malaysian civil service.

Apart from that, application figures for the Malaysian Administrative and Diplomatic Service (Pegawai Tadbir dan Diplomatik, PTD) in 1995 showed that the 200 entry positions in that year attracted a total of 1,462 eligible candidates, of which 1,296 (88.7\%) graduated from local (public) universities while 166 (11.4\%) graduated from foreign universities but there was none from local private universities (Abdullah, Norma and Abdul 2003). ${ }^{3}$ Even though PTD is seen as the most sought after job in the market (Administrative and Diplomatic Office 2016; Saupee 2012), surprisingly not even one job-seeker that graduated from a local private tertiary institution applied for it. Social inclusion and equity is the foundation for sustainable development in a plural society (Dugarova and Lavers 2015), and viewing from this perspective, the low representation of non-Malays in the public sector together with the non-existence of applications from private college graduates for the most sought after public sector position are questions that are worth pondering over.

The low number of applications and low interest of non-Malays were often cited as the reasons for the low representation of non-Malays in the civil service (FMT Reporters 2015). Moreover, a study showed that students in private tertiary 
institutions in Malaysia are predominantly non-Malay (Wan 2007). This seems to explain and reinforce the wide speculation of the unattractiveness of public employment to private tertiary institution graduates. The issue of unattractiveness of government jobs to private tertiary institution students in Malaysia has yet to be adequately addressed by scholars. This study is an attempt to fill the gap.

The pool of private tertiary institution graduates is significant for the public-sector renewal. Also, it is essential for most, if not all, students to be ready for their careers when they graduate from colleges. However, most students do not know which career they will pursue and what they are looking for in a job after graduation. This fact alone makes it important to identify factors that influence career choice.

Specifically, this study aims to examine three research questions. First, what are the factors that are important to private college graduate job seekers in considering a career? Second, how do private college graduates perceive the attractiveness of various job characteristics in the public sector compared to the private sector? Third, how do various factors impact the likelihood of private college graduates in considering public employment? Answers to these questions are useful to public personnel managers or policymakers, employers, and career counsellors in devising effective measures in attracting talents to their organisations or in advising students.

\section{FACTORS AFFECTING CAREER CHOICE}

Generally, three broad factors are identified from most career choice theories. They are job and organisational characteristics, background and demographic characteristics, and personal characteristics (hereafter referred to as job characteristics, background characteristics, and personal characteristics). The selection of these characteristics is guided by existing and almost entirely western studies of career choice. A prominent feature of these studies is that they include partly different variables because of the selection of variables that may be important or interesting in the local situation. This study follows suit and selects factors that are regarded as matters of concern in the Malaysian context.

\section{Job Characteristics}

In general, the most commonly cited factor that affects graduates' career choice is job characteristics. Job characteristics are said to have an impact on one's career choice and include salary, job security, public service motivation (PSM), ${ }^{4}$ freedom from supervision, freedom from undue strain, amount of travel involved, social interaction, interesting and challenging job, stress level of job, promotion 
prospects, job satisfaction, image, working environment, autonomy, and representative/multiracial workplace (Alexander et al. 2011; Christensen and Wright 2011; Gupta and Houtz 2000; Lee and Wilkins 2011; Lewis and Frank 2002; McGraw et al. 2012; Rettenmayer, Berry and Ellis 2007; Swinhoe 1967; Walstrom et al. 2008; Woo 2011; 2017). This study examines 10 job characteristics, i.e. pay and financial rewards, promotion prospects, job security, autonomy, interesting and challenging job, job satisfaction, image, stress level of job, representative/ multiracial workplace, and PSM.

\section{Background Characteristics}

Background characteristics, which shape one's values and beliefs, are commonly discussed as an important factor that will impact an individual's career decision. The background variables that are included in the study are family income, gender, and type of primary and secondary schools attended. Studies show that a person's family background and socio-economic status are important influential factors of his/her career choice (Stritch and Christensen 2016; Tang, Fouad and Smith 1999). Shumba and Naong (2013) found that $69.2 \%$ of their respondents bemoaned either a lack of or inadequate family income as the most common impediment towards realising their chosen career choice. Meanwhile, a study from Brazil suggests that individuals will adjust career plans and choices according to their socioeconomic conditions (Leitão et al. 2013). In many countries including Malaysia, the participation of women in the labour force has greatly increased and many women work outside the home for a substantial part of their lives. This raises an interesting question: Is public employment more attractive to women than to men? Some studies in the US have answered this question in the positive (Hull and Nelson 2000; Kilpatrick, Cummings and Jennings 1964; Lewis and Frank 2002). Studies also demonstrate that the likelihood of women's choice to work for the government is correlated to job characteristics (Konrad et al. 2000; Tolbert and Moen 1998). As for educational background, people who attend different types of school experience significantly different types of socialisation. The resulting differences in values and beliefs may dispose them toward different choices of career. Malaysia is a multiracial country, and this has shaped its education system. There are two types of public primary schools, i.e. national and vernacular. Vernacular primary schools consist of Chinese and Tamil primary schools. There are also two types of public secondary schools, i.e. national and Chinese. Woo $(2011 ; 2017)$ found that those who attended Chinese schools were less likely to work in the public sector. 


\section{Personal Characteristics}

Language proficiency and academic performance affect one's career choice. Woo (2011) observed that Malaysian public university graduates with a better Malay language proficiency were more likely to serve in the government sector while English language was found to be irrelevant in graduates' career choice. However, in another study on private tertiary institutions, Woo (2017) found that private college graduates with good proficiency in both the English and Malay languages were more attracted to public employment. As for academic performance, studies showed that individuals who chose to work with the government were normally highly educated and with more experiences (Blank 1985). Nevertheless, Kilpatrick, Cummings and Jennings (1964), and Woo (2011; 2017) found no correlation between academic performance and graduates' public employment. In other words, findings on the relationship between academic performance and working for the government are mixed. Language proficiency and academic performance are two variables to be studied under the personal characteristic factor in the current research. In this study, language proficiency will be referred to as English language proficiency and Malay language proficiency.

\section{RESEARCH METHOD}

\section{Population, Sample and Data Collection}

This study examines the choice of 1,290 final year students of a private college in choosing either public or private employment. All final year students of the private college, located in the northern region of Peninsular Malaysia, were involved in the study except those who were not available and absent during the period when the study was conducted. Appropriate data was obtained through a crosssectional survey, by administering a questionnaire, from April to October 2016. A total number of 1,430 questionnaires were distributed and 1,311 were collected back. The overall response rate for the study was $91.7 \%$. Of the 1,311 collected questionnaires, 1,290 were usable. The population size was 3,434 and the sample size of 1,290 makes a confidence interval of 2.16 and a confidence level of $95 \%$ (Creative Research Systems 2017). Table 1 shows the distribution of the study's population and sample by race and gender. As shown in the table, the racial and gender compositions of the sample closely approximate that of the population from which the sample was drawn. 
Table 1: The study's population and sample by race and gender

\begin{tabular}{|c|c|c|c|c|c|c|c|c|}
\hline & & \multicolumn{2}{|c|}{ Gender } & \multicolumn{4}{|c|}{ Race } & \multirow{2}{*}{ Total } \\
\hline & & Male & Female & Chinese & Indians & Malays/Bumi* & Others & \\
\hline \multirow[t]{2}{*}{ Population } & $\mathrm{N}$ & 1,530 & 1,904 & 3,354 & 59 & 15 & 6 & 3,434 \\
\hline & $\%$ & 44.6 & 55.4 & 97.7 & 1.7 & 0.4 & 0.2 & 100 \\
\hline \multirow[t]{2}{*}{ Sample } & $\mathrm{N}$ & 524 & 757 & 1,267 & 18 & 3 & 2 & 1,290 \\
\hline & $\%$ & 40.6 & 58.7 & 98.2 & 1.4 & 0.2 & 0.2 & 100 \\
\hline
\end{tabular}

Note: Bumi*: Bumiputera

\section{Data Analysis}

A data file was set up using Statistical Product and Service Solutions (SPSS). Job characteristics have an important influence on job choice of most job seekers, if not all. A total of 10 job characteristics were identified to be included in this study. Based on a Likert scale ranging from 1 to 5 , respondents were asked to indicate the importance they attach to each job characteristic and its attractiveness in the public sector. It is understood that when evaluating the attractiveness of a job, most job seekers rarely evaluate the job based on a single characteristic but instead consider all characteristics. In addition, whenever any two respondents rate public job characteristics to be equally attractive, this does not suggest that both will be attracted to public sector jobs. It also depends on the importance they attach to those job characteristics. It is therefore better to weigh the respondent's rating of the attractiveness of each job characteristic by his/her rating of its importance.

Therefore, an index of public employment attractiveness (Attrctv) was constructed based on the weighted ratings of attractiveness for all the 10 job characteristics that were included in the study. In terms of importance and attractiveness (Questions 1 and 2 of Part A of the questionnaire), each job characteristic was rated from 1 to 5 on the Likert scale. Multiplying the two ratings provided the weighted rating of attractiveness. The minimum weighted rating of attractiveness for each job characteristic was $1(1 \times 1)$ and its maximum was 25 $(5 \times 5)$. Hence, the index of each job characteristic ranged from 1 to 25 . The weighted ratings of attractiveness of the 10 job characteristics were then summed up to create the index of public employment attractiveness (Attrctv), ranging from $10(1 \times 10)$ to $250(25 \times 10)$. The midpoint of the index was 130 . Indices at or lower than the midpoint indicated Low Attractiveness, and those above the midpoint indicated High Attractiveness.

In this study, mean rating, contingency table analysis, and logistic regression were used to analyse the data. One-way analysis of variance (ANOVA) was used to test the significance of differences among respondent subgroups. Respondents reported whether they are likely or unlikely to choose public employment. 
The logistic regression model was used to assess the factors that influenced the dichotomous sectoral preference of public or non-public employment. When the dependent variable is dichotomous, use of the ordinary least squares model violates the constant error variance assumption and produces inefficient estimators. Hence, the binary choice logistic regression model was deemed more appropriate (Miles and Shevlin 2003; Gujarati 2003). The chi-square statistic was used to test the significance of the model. In general, the dichotomous-choice logistic regression model can be written as follows:

$$
\log [\mathrm{P} /(1-\mathrm{P})]=\beta_{0}+\beta_{1} \mathrm{X}_{1}+\ldots+\beta_{\mathrm{k}} \mathrm{X}_{\mathrm{k}}+\varepsilon
$$

where

$\mathrm{P}=$ the probability of choosing public employment;

$\mathrm{X}=$ explanatory variable hypothesised to influence $\mathrm{P}$;

$\beta=$ coefficient for explanatory variable; and

$\varepsilon=$ stochastic disturbance term.

Table 2 shows the Variable, Description, and Exp. Sign (expected sign of coefficient) for the explanatory variables. A description of how these variables were coded follows. The dependent variable JobChoice is a dichotomised variable. Respondents who indicated that they are likely to choose public employment took a value of 1 while those who indicated they are unlikely to choose public employment took a value of 0 .

Table 2: Description of explanatory variables in the statistical model

\begin{tabular}{llc}
\hline Variable & Description & Exp. Sign \\
\hline Attrctv & $\begin{array}{l}1 \text { if indices fall above 130 to 250 indicate High Attractive; 0 if indices } \\
\text { fall from 10 to 130 indicate Low Attractive }\end{array}$ & + \\
Income & $\begin{array}{l}1 \text { if respondent's monthly family income above RM5,000; 0 if at or } \\
\text { below RM5,000 }\end{array}$ & - \\
Gender & 1 if male; 0 if female & - \\
PrimSch & 1 if respondent had not attended SJK (C)*; 0 if attended & + \\
SecSch & 1 if respondent had not attended SMK ; 0 if attended & - \\
CGPA & Cumulative Grade Point Average of respondent & $\mathrm{n} / \mathrm{a}$ \\
MalayPro & $\begin{array}{l}1 \text { if respondent obtained at least a credit pass (Grade C) in SPM } \\
\text { examination, indicates Good proficiency in Malay; 0 if not }\end{array}$ & + \\
EngPro & $\begin{array}{l}1 \text { if respondent obtained grades A+, A or A- in SPM examination, } \\
\text { indicates Excellent proficiency in English; 0 if not }\end{array}$ & - \\
\hline
\end{tabular}

*SJK (C), Chinese primary school

** SMK, national secondary school

${ }^{* * *}$ SPM examination is a national examination taken by all fifth-year secondary school students in Malaysia 
All the independent variables were dichotomous (and dummy coded) except for CGPA (academic performance). The majority group of all independent variables took a value of 0 and was used as the base for comparison with other groups except for the variable of Malay language proficiency (MalayPro). For convenient interpretation, the majority group for the variable of MalayPro took a value of 1 (instead of 0 ).

The index Attrctv was used for job characteristics. It was dichotomised at its midpoint of 130. Indices of High Attractiveness (131 to 250) took a value of 1 while indices of Low Attractiveness (10 to 130) took a value of 0 . Graduate job seekers who view public employment as High in attractiveness are more likely to choose a public-sector career. Thus, the relationship between public employment and Attrctv was expected to be positive.

The background characteristics included as independent variables in the model were family income (Income), gender (Gender), type of primary school attended (PrimSch), and type of secondary school attended (SecSch). For the variable Income, the value 0 denoted those whose monthly family income was at or below RM5,000, and 1 was for those whose monthly family income was above RM5,000. Literature review showed that individuals with lower economic background were more attracted to public employment (Daniel and Encel 1981; Kilpatrick, Cummings and Jennings 1964). Thus, the relationship between public employment and Income was expected to be negative. For Gender, female took a value of 0 while 1 was for male. Literature review revealed that women were more attracted by public employment compared to men. This study expected likewise, hence, the sign of the coefficient for gender was expected to be negative. The variable PrimSch took a value of 0 for those who attended Chinese primary school (SJK [C]), and 1 otherwise. SecSch took a value of 0 for those who attended national secondary school (SMK) and 1 for those who did not attend SMK. Respondents who did not attend SMK would mostly have attended Chinese secondary schools. There is a lack of empirical studies on the influence of school type on the choice of public employment in western studies. In the Malaysian context, Woo (2011; 2017) found that graduates who attended Chinese schools were negatively related to the probability of considering public sector jobs. As such, the effect of attending Chinese primary school (SJK [C]) on the choice of public employment was expected to be negative while the relationship between attending SMK and public employment was expected to be positive.

The final group of independent variables, namely personal characteristics, concern academic performance (CGPA), Malay language proficiency (MalayPro), and English language proficiency (EngPro). The data on respondents' $C G P A$ was in continuous numbers, ranging from 1.00 to 4.00 . Literature review indicated that academic performance had no clear relationship with the attractiveness of public sector jobs. Hence, the coefficient for this variable has no expected sign in the 
table. For the variable MalayPro, value of 1 was assigned to those who obtained at least a Grade $\mathrm{C}$ (credit pass) and 0 to those who did not. Malay language is the main language used in the public sector. A credit (Grade C) in SPM examination is one of the requirements for entering the Malaysian civil service, especially for the Management and Professional Group. Hence, the relationship between choosing government jobs and MalayPro was expected to be positive. As for EngPro, the value 1 was assigned to respondents who obtained grades $\mathrm{A}+, \mathrm{A}$, and $\mathrm{A}-$ (excellent) and 0 to those who did not. English proficiency is valued in the private sector where the language is widely used even though it is useful in both the public and private sectors. Viewing from this perspective, it is a greater disability in the private sector if one is not proficient in English language, and hence s/he will avoid a career in the private sector and look for a job in the public sector instead. Thus, the relationship between them was expected to be negative.

\section{FINDINGS AND DISCUSSION}

\section{Important Factors for Choosing a Career}

Respondents were asked to rate in terms of importance 10 job characteristics that were listed in Question 1 of the questionnaire. The rating of importance based on the Likert scale ranged from 1 to 5 (very not important to very important). Respondents were allowed to state job characteristics that they see as important apart from those listed in the column "other" provided in Question 1 (the importance of job characteristics), Question 2 (the attractiveness of public job characteristics), and Question 3 (comparison of job characteristics offered by the public and private sectors). However, less than $2 \%$ answered this part for all three questions, suggesting that the listed characteristics included all those commonly regarded as important by respondents. Hence, discussion will be restricted to the 10 listed job characteristics.

Table 3 shows respondents' ratings in terms of importance of the listed job characteristics. The job characteristics were ranked in the following order: pay and financial rewards (4.65), job security (4.61), promotion prospects (4.37), job satisfaction (4.36), autonomy (4.08), image (4.07), low job stress (3.88), interesting and challenging job (3.87), public service motivation (3.47), and representative/ multiracial workplace (3.43). Extrinsic rewards or material rewards, which include pay and financial rewards, job security, and promotion prospects, were the most important motivators. These three job characteristics are related to the material rewards from the job at current stage and in the future. The higher ratings of the first three job characteristics compared to others thus show the primacy of extrinsic material rewards in affecting job choice. The second and third clusters 
of motivators that emerged with the ranking were intrinsic and ego intensives (job satisfaction, autonomy, interesting and challenging job, and public service motivation), and organisational image and work conditions (image, low job stress, and representativeness/multiracial workplace). The former group of motivators concerns personal sense of achievement and satisfaction while the latter group of motivators is related to organisational prestige and environment.

Table 3: The importance of job characteristics

\begin{tabular}{lccc}
\hline & $\mathrm{N}$ & $\mathrm{M}$ & $\mathrm{SD}$ \\
\hline Pay and financial rewards & 1,288 & 4.65 & 0.578 \\
Job security & 1,288 & 4.61 & 0.651 \\
Promotion prospects & 1,288 & 4.37 & 0.738 \\
Job satisfaction & 1,279 & 4.36 & 0.709 \\
Autonomy & 1,286 & 4.08 & 0.799 \\
Image & 1,287 & 4.07 & 0.841 \\
Low job stress & 1,285 & 3.88 & 1.002 \\
Interesting and challenging job & 1,288 & 3.87 & 0.878 \\
Public service motivation & 1,287 & 3.47 & 1.033 \\
Representative/multiracial workplace & 1,284 & 3.43 & 1.076 \\
Others & 23 & 4.52 & 0.665 \\
\hline
\end{tabular}

Note: M: Mean; SD: Standard deviation

The respondents were final-year college students about to begin gainful employment. Once employed, they are expected to be self-supporting and perhaps financially help family members as well. It is hardly surprising for them to put primary importance on material rewards, especially pay. Later on, when they enjoy higher pay and have more savings, they may put more importance on non-material factors (the second and third groups of motivators).

The above results indicate that respondents generally placed considerable value on the job characteristics included in this study. All these job characteristics are therefore important factors in career choice. The mean ratings of all job characteristics were above 4 (Important), except for low job stress, interesting and challenging job, public service motivation, and representativeness/multiracial workplace (Table 3). Even the two lowest rated characteristics had mean ratings close to the midpoint of the 5-point scale.

Respondents of the study were final year students pursuing a bachelor's degree or diploma. What a job would offer vary according to one's level of educational qualification. The following part examines variation in the importance of job characteristics to respondent subgroups according to the level of educational qualification. Table 4 shows the importance of job characteristics according to 
respondents' level of qualification. Of the 10 job characteristics, five were found to have statistically significant differences among subgroups, i.e. pay and financial rewards, job security, autonomy, image, and low job stress.

Table 4: The importance of job characteristics by levels of qualification

\begin{tabular}{|c|c|c|c|c|c|c|c|c|c|c|c|}
\hline $\begin{array}{l}\text { Level of } \\
\text { qualification }\end{array}$ & & A & B & $\mathrm{C}$ & $\mathrm{D}$ & E & $\mathrm{F}$ & G & $\mathrm{H}$ & I & $\mathrm{J}$ \\
\hline \multirow[t]{2}{*}{ Diploma } & $\mathrm{M}$ & 4.67 & 4.37 & 4.63 & 4.10 & 3.86 & 4.36 & 4.10 & 3.43 & 3.92 & 3.47 \\
\hline & $\mathrm{N}$ & 1,086 & 1,086 & 1,086 & 1,079 & 1,084 & 1,085 & 1,083 & 1,086 & 1,085 & 1,082 \\
\hline \multirow[t]{2}{*}{ Degree } & M & 4.54 & 4.35 & 4.53 & 3.97 & 3.93 & 4.39 & 3.93 & 3.41 & 3.67 & 3.45 \\
\hline & $\mathrm{N}$ & 202 & 202 & 202 & 200 & 202 & 202 & 202 & 202 & 202 & 202 \\
\hline$F$ sta. & & 9.007 & 0.175 & 4.117 & 4.770 & 1.199 & 0.241 & 6.612 & 0.079 & 10.002 & 0.091 \\
\hline$p$-value & & $0.003^{* * *}$ & 0.676 & $0.043^{* * *}$ & $0.029^{* *}$ & 0.274 & 0.623 & $0.010^{* * *}$ & 0.779 & $0.002^{* * *}$ & 0.762 \\
\hline
\end{tabular}

Notes: *** Significant at 0.01 level; *" Significant at 0.05 level; "Significant at 0.10 level; M: Mean

A: Pay and financial rewards; B: Promotion prospects; C: Job security; D: Autonomy; E: Interesting and challenging job; F: Job satisfaction; G: Image; H: Representative/multiracial workplace; I: Low job stress; J: Public service motivation

Generally, the offer of a job will be directly related to one's level of educational qualification: the higher the qualification one has obtained, logically, the better offer one will get and hence affect one's attachment to job characteristics. According to Stahl $(1966,199)$, in an affluent society with a high minimum standard of "creature comfort", material rewards are rarely the number one factor that determines career choice. However, the situation is likely to be different in developing countries, including Malaysia, where material rewards for meeting physical needs are the main concern among job seekers. More so for respondents with diplomas whereby normally they would receive lower offers compared to degree holders. The findings on respondents with diplomas who attached high importance not only to pay but also to job security lends support to Stahl's argument. The higher attachment of respondents with diplomas to the job characteristics of autonomy, image, and low job stress compared to respondents with bachelor's degrees probably have something to do with prestige and capacity. Unlike degree holders who are more likely to be able to get a position at management level, diploma holders are more likely to get jobs in which they must work under the supervision of management level personnel. Thus, they would probably value more jobs with lower job demands and jobs in which they can work independently without the interference of superiors.

\section{The Perceived Attractiveness of Public Job Characteristics}

Question 2 of the questionnaire asked respondents to rate the attractiveness of public sector jobs in terms of each of the 10 listed job characteristics. The Likert 
scale used for this rating ranged from 1 to 5 (very poor to very good). Table 5 shows respondents' mean ratings of job characteristics in the public sector. Job security, with a mean rating of 3.58 , was considered as the most attractive job characteristic, followed by low job stress (3.36), pay and financial rewards (3.27), public service motivation (3.13), representative/multiracial workplace (3.47), job satisfaction (2.91), image (2.88), promotion prospects (2.87), autonomy (2.83), and finally interesting and challenging job (2.72). The ratings ranged from 3.58 to 2.72. Only four public job characteristics - job security, low job stress, pay and financial rewards, and public service motivation - were rated positively (or above average). This may suggest that respondents do not have a very high evaluation of public job characteristics.

Table 5: The attractiveness of public job characteristics

\begin{tabular}{lccc}
\hline & $\mathrm{N}$ & $\mathrm{M}$ & $\mathrm{SD}$ \\
\hline Job security & 1,272 & 3.58 & 0.963 \\
Low job stress & 1,270 & 3.36 & 1.060 \\
Pay and financial rewards & 1,274 & 3.27 & 1.009 \\
Public service motivation & 1,276 & 3.13 & 1.048 \\
Representative/multiracial workplace & 1,275 & 2.98 & 1.099 \\
Job satisfaction & 1,274 & 2.91 & 1.023 \\
Image & 1,275 & 2.88 & 1.057 \\
Promotion prospects & 1,274 & 2.87 & 0.977 \\
Autonomy & 1,274 & 2.83 & 1.028 \\
Interesting and challenging job & 1,269 & 2.72 & 0.975 \\
Others & 11 & 2.09 & 1.221 \\
\hline
\end{tabular}

Note: M: Mean; SD: Standard deviation

Table 6 shows the attractiveness of public job characteristics to respondents according to level of educational qualification. As indicated in the table, seven out of the 10 public job characteristics showed statistically significant differences in ratings among respondent subgroups. The ratings of all these seven job characteristics showed an inverse relationship with level of educational qualification. In other words, respondents with a higher level of qualification (degrees) had lower ratings while those with a lower level of qualification (diplomas) had higher ratings for these public job characteristics. 
Table 6: The attractiveness of public job characteristics by levels of qualification

\begin{tabular}{|c|c|c|c|c|c|c|c|c|c|c|c|}
\hline $\begin{array}{l}\text { Level of } \\
\text { qualification }\end{array}$ & & A & B & $\mathrm{C}$ & $\mathrm{D}$ & E & $\mathrm{F}$ & $\mathrm{G}$ & $\mathrm{H}$ & I & $\mathrm{J}$ \\
\hline \multirow[t]{2}{*}{ Diploma } & $\mathrm{M}$ & 3.46 & 2.89 & 3.74 & 2.95 & 2.76 & 3.09 & 3.06 & 3.20 & 3.46 & 3.30 \\
\hline & $\mathrm{N}$ & 199 & 199 & 200 & 200 & 200 & 198 & 199 & 198 & 199 & 197 \\
\hline \multirow[t]{2}{*}{ Degree } & M & 3.24 & 2.86 & 3.55 & 2.81 & 2.71 & 2.88 & 2.85 & 2.94 & 3.35 & 3.10 \\
\hline & $\mathrm{N}$ & 1,073 & 1,071 & 1,074 & 1,076 & 1,075 & 1,076 & 1,076 & 1,076 & 1,075 & 1,072 \\
\hline$F$ sta. & & 8.070 & 0.187 & 6.574 & 2.935 & 0.333 & 6.738 & 6.718 & 9.367 & 1.790 & 6.151 \\
\hline$p$-value & & $0.005^{* * * *}$ & 0.665 & $0.010^{* * *}$ & $0.087^{*}$ & 0.564 & $0.010^{* * *}$ & $0.010^{* * * *}$ & $0.002^{* * * *}$ & 0.181 & $0.013^{* *}$ \\
\hline
\end{tabular}

Notes: ***Significant at 0.01 level; **Significant at 0.05 level; *Significant at 0.10 level; M: Mean

A: Pay and financial rewards; B: Promotion prospects; C: Job security; D: Autonomy; E: Interesting and challenging job; F: Job satisfaction; G: Image; H: Representative/multiracial workplace; I: Low job stress; J: Public service motivation

The greater attractiveness of public job characteristics to respondents with diplomas compared to those with degrees lend some support to Lucas and Verry's (1999) argument, whereby due in part to pay compression or the practice of keeping pay differences within bounds, public sector job characteristics, especially pay in Malaysia is often said to be less attractive to bachelor degree than to non-bachelor degree holders.

To investigate the perceived attractiveness of job characteristics in the public and private sectors, respondents were asked to compare the attractiveness of job characteristics offered by the public and private sectors. Question 3 of the questionnaire asked respondents to compare the attractiveness between the public and private sectors by rating the attractiveness in terms of each of the 10 listed job characteristics in the two sectors. The Likert scale used for this rating ranged from 1 to 5 (very low to very high). Table 7 shows the comparison of rankings of each of the 10 job characteristics in the public and private sectors. As indicated in the table, only the public job characteristics of job security (3.57), public service motivation (3.31), pay and financial rewards (3.28), low job stress (3.25), and representativeness/multiracial workplace (3.15) were rated slightly above 3 , while others were rated around 2 (Low Attractive) on the 5-point Likert scale.

Contrary to the public sector, the ratings of all job characteristics of the private sector were above the mid-point on the 5-point Likert scale in terms of attractiveness and the job characteristics of pay and financial rewards, and image were rated above 4 . In short, compared to the private sector, respondents of the study perceived the offer of public sector jobs is lower (in terms of attractiveness) than what would be offered by private sector jobs. Perception guides behaviour, thus this not very positive perception of the respondents toward public employment would very likely affect their sectoral preferences. 
Table 7: Job characteristics: The public sector and private sector compared

\begin{tabular}{lcccccccc}
\hline & \multicolumn{3}{c}{ Private sector } & & \multicolumn{3}{c}{ Public sector } \\
\cline { 2 - 3 } & $\mathrm{N}$ & $\mathrm{M}$ & $\mathrm{SD}$ & & $\mathrm{N}$ & & $\mathrm{M}$ & $\mathrm{SD}$ \\
\hline Pay and financial rewards & 1,282 & 4.11 & 0.765 & & 1,278 & 3.28 & 0.927 \\
Image & 1,282 & 4.02 & 0.774 & & 1,273 & 2.97 & 1.029 \\
Interesting and challenging job & 1,280 & 3.94 & 0.799 & & 1,275 & 2.76 & 0.919 \\
Promotion prospects & 1,278 & 3.92 & 0.772 & & 1,277 & 2.94 & 0.918 \\
Job satisfaction & 1,282 & 3.88 & 0.758 & & 1,274 & 2.98 & 0.934 \\
Job security & 1,280 & 3.78 & 0.809 & & 1,277 & 3.57 & 0.944 \\
Autonomy & 1,282 & 3.70 & 0.826 & & 1,273 & 2.93 & 0.948 \\
Low job stress & 1,277 & 3.47 & 0.986 & & 1,279 & 3.25 & 1.069 \\
Representative/multiracial workplace & 1,277 & 3.45 & 0.914 & & 1,276 & 3.15 & 1.138 \\
Public service motivation & 1,267 & 3.37 & 0.907 & & 1,265 & & 3.31 & 1.087 \\
\hline
\end{tabular}

Note: M: Mean; SD: Standard deviation

\section{The Pull and Push Factors of Public Employment}

Respondents were asked to indicate their job preference in the questionnaire. The sample of respondents therefore consisted of two groups, i.e. choosers and nonchoosers of public sector jobs. Table 8 indicates the employment preference of respondents by sector.

Table 8: Respondents' employment preference

\begin{tabular}{lcc}
\hline Job choice & $\mathrm{N}$ & $\%$ \\
\hline Public sector & 139 & 10.8 \\
Non-public sector & 1,146 & 89.2 \\
\hline Total & 1,285 & $100 \%$ \\
\hline
\end{tabular}

As indicated in the Table 8 , only $10.8 \%$ or 139 respondents would consider public sector jobs after graduation. Attracting sufficient human resource is vital in maintaining the sustainability and innovation of any organisation. Hence, the questions that should be raised here are: what are the factors that push the $89.2 \%$ respondents away from public employment and what are the pull factors that attracted the $10.8 \%$ respondents to consider public sector jobs. To examine these factors, two open-ended questions asking respondents to state up to three factors that pull/push them to/from public employment were posted in the questionnaire. This was to provide an opportunity which allows respondents the freedom to state the factors they see as operative and strong enough to attract/deter them to/from public employment. 
Table 9 indicates the pull factors cited by choosers of public employment. In order of importance, the three main pull factors are pay and fringe benefits, low job stress, and job security. These three factors accounted for $84.1 \%$ or more than fourth-fifths of total cites. The percentage of choosers citing each of these factors ranged from $42.3 \%$ to $15.5 \%$. Other pull factors, each of which accounted for less than $15 \%$ of total cites, include public service motivation (4.2\%), promotion prospects $(3.3 \%)$, no other choice $(2.8 \%)$, interesting and challenging jobs $(1.9 \%)$, and others $(3.8 \%)$.

Table 9: Factors cited for choosing public sector jobs

\begin{tabular}{lccc}
\hline Factors & No. of cites & $\begin{array}{c}\text { Total cites }(\%) \\
(\mathrm{N}=213)\end{array}$ & $\begin{array}{c}\text { Choosers citing (\%) } \\
(\mathrm{N}=139)\end{array}$ \\
\hline Pay and fringe benefits & 90 & 42.3 & 64.7 \\
Low job stress & 56 & 26.3 & 40.3 \\
Job security & 33 & 15.5 & 23.7 \\
Public service motivation & 9 & 4.2 & 6.5 \\
Promotion prospects & 7 & 3.3 & 5.0 \\
No other choice & 6 & 2.8 & 4.3 \\
Interesting and challenging jobs & 4 & 1.9 & 2.9 \\
Others & 8 & 3.8 & 5.8 \\
\hline
\end{tabular}

The top three pull factors were related to material rewards (pay and fringe benefits, and job security) and work condition (low job stress). This finding suggests that the ability of public employment to provide sufficient material rewards and a better work-life balance is the main attraction of public employment to college graduates. Following the top three pull factors was the intrinsic reward of public service motivation (PSM). The finding of PSM as one of the main pull factors is a positive sign as PSM is a distinctive motive scholars argue for preferring public employment (Perry and Wise 1990). The findings on material rewards, work condition, and intrinsic reward as pull factors are broadly consistent with the ratings of the attractiveness of public job characteristics as discussed in earlier parts.

Table 10 shows that low pay, poor promotion prospects, discrimination, not interesting and challenging job, and negative image and working culture, are the five most important factors that made respondents avoid public sector jobs. These factors together accounted for $76.4 \%$ or more than three quarters of total cites. As indicated in Table 3, the three job characteristics that turned out to be the main push factors, namely pay, promotion prospects, and interesting and challenging job, were rated above 4 or close to 4 in terms of importance by respondents. 
In terms of attractiveness in the public sector, however, these job characteristics were rated relatively lower, i.e. from 2.72 to 3.58 , as shown in Table 5. This turned out to be enough to make these factors responsible for pushing a great number of private college graduate job seekers away from public employment.

Table 10: Factors cited for not choosing public sector jobs

\begin{tabular}{lccc}
\hline Factors & $\begin{array}{c}\text { No. of } \\
\text { cites }\end{array}$ & $\begin{array}{c}\text { Total cites }(\%) \\
(\mathrm{N}=1,845)\end{array}$ & $\begin{array}{c}\text { Non-choosers citing (\%) } \\
(\mathrm{N}=1,146)\end{array}$ \\
\hline Low pay & 449 & 24.3 & 39.2 \\
Poor promotion prospects & 282 & 15.3 & 24.6 \\
Discrimination & 273 & 14.8 & 23.8 \\
Not interesting and challenging jobs & 229 & 12.4 & 20.0 \\
Negative image and working culture & 178 & 9.6 & 15.5 \\
Low opportunity to be recruited & 108 & 5.9 & 9.4 \\
Low autonomy & 125 & 6.8 & 10.9 \\
Poor working environment & 85 & 4.6 & 7.4 \\
Poor Malay language skill & 27 & 1.5 & 2.4 \\
Others & 89 & 4.8 & 7.8 \\
\hline
\end{tabular}

In view of the increasingly mono-ethnic Malaysian civil service (Chin 2011; FMT Reporters 2015; Lim 2013; Woo 2015), the third and sixth push factors of discrimination and low opportunity to be recruited into the public-sector merits further discussion. To shed more light on this (anticipated) factor, two questions (Q13 and Q14) on equal treatment in the public sector were posted in the questionnaire. Respondents were asked to rate the questions from 1 (strongly disagree) to 5 (strongly agree). Q13 concerns promotion while Q14 concerns recruitment. Question 13 reads, "All people who are working in the public sector, regardless of their race, have equal chance of promotion", while Question 14 reads, "All people, regardless of their race, have equal chance to be recruited into the public sector." From Table 11, it is obvious that respondents disagree that there are equal chances in recruitment and promotion in the public sector. The mean ratings for both questions were below the scale midpoint, i.e. 2.42 and 2.58. The results seem to confirm the prevalent belief among minorities, especially Chinese, that equal treatment in terms of recruitment and promotion are not given to all regardless of racial group. 
Table 11: Respondents' mean ratings of equal treatment

\begin{tabular}{lccc}
\hline & $\mathrm{N}$ & $\mathrm{M}$ & $\mathrm{SD}$ \\
\hline Equal chance of promotion & 1,286 & 2.42 & 1.248 \\
Equal of recruitment & 1,287 & 2.58 & 1.248 \\
\hline
\end{tabular}

Note: M: Mean; SD: Standard deviation

Next, the study examined how various factors affect private college graduates' sectoral preference. Logit regression was used to simultaneously assess the effect of independent variables (various factors) on the likelihood of private college graduates in considering public employment. Table 12 presents the estimated coefficients, standard errors, odds ratio, and marginal effects of the model specified earlier in Research Method.

Table 12: Effect of independent variables on choice of public employment: summary statistics of the logit model

\begin{tabular}{lccccc}
\hline $\begin{array}{l}\text { Independent } \\
\text { variable }\end{array}$ & $\begin{array}{c}\text { Coeff. } \\
(\mathrm{b})\end{array}$ & Std. errors & $\begin{array}{c}\text { Odds ratio exp } \\
(\mathrm{b})\end{array}$ & $p$-value & $\begin{array}{c}\text { Marginal } \\
\text { effect }\end{array}$ \\
\hline Constant & -2.430 & 0.666 & 0.088 & 0.000 & - \\
Attrctv & 0.495 & 0.193 & 1.641 & $0.010^{* * *}$ & -0.0593 \\
Income & -0.576 & 0.275 & 0.562 & $0.036^{* *}$ & -0.0671 \\
Gender & 0.198 & 0.197 & 1.219 & 0.315 & 0.0299 \\
PrimSch & 0.340 & 0.380 & 1.405 & 0.371 & 0.0537 \\
SecSch & -0.359 & 0.205 & 0.698 & $0.080^{*}$ & -0.0451 \\
CGPA & -0.100 & 0.199 & 0.905 & 0.617 & 0.2957 \\
MalayPro & 0.666 & 0.358 & 1.946 & $0.063^{*}$ & -0.0751 \\
EngPro & -0.095 & 0.237 & 0.910 & 0.690 & -0.0130 \\
\hline
\end{tabular}

Notes: Model Chi-square $=22.664$ (significant at 0.004 level); Likelihood ratio statistics $=767.798$; Percent of correct predictions $=89.1 \%$

${ }^{* * *}$ Significant at 0.01 level (99\% confidence level); ${ }^{* *}$ Significant at 0.05 level ( $95 \%$ confidence level); ${ }^{*}$ Significant at 0.10 level $(90 \%$ confidence level)

The specified model was statistically significant as evidenced by the Likelihood Ratio test $(\mathrm{LR})=767.798$ and the probability value of almost zero. Thus, the null hypothesis $\left(\mathrm{H}_{0}\right)$ that all the coefficients are zero at the $99 \%$ confidence level of significance is rejected. The model was also found to be a relatively good fit, as it correctly predicts $89.1 \%$ of the outcomes in the sample and is therefore deemed a good fit or useful for enhancing prediction of the likelihood of private college graduating students choosing public employment. Of the eight independent variables, four were statistically significant in affecting the likelihood of private college graduating students choosing public employment. Impacts of the 
specific explanatory variables on choosing government jobs decision are further discussed below.

Attrctv. The index of public employment attractiveness was statistically significant and negatively related to the probability of choosing public employment. Respondents who rated public employment as High in attractiveness are less likely to choose public employment than those who rated it as Low in attractiveness. The odds or likelihood of the former group choosing public employment was 1.641 times that of the latter group. In addition, the probability of choosing government jobs decreased by $5.9 \%$ for those who rated the index as High in attractiveness than those who rated it as Low. The results are perplexing as usually when one perceived a job is attractive $\mathrm{s} / \mathrm{he}$ is more likely to choose the job instead of the other way around. This is probably related to the perception of discrimination treatment against minorities in the public sector as discussed earlier. Due to the prevalence of the negative perception, this factor alone is enough to deter private graduate job seekers (mostly from minority groups) from considering public employment and thus making other factors secondary.

Income. Family income was statistically significant and negatively related to the likelihood of choosing a government job. Respondents with monthly family income above RM5,000 were 0.562 times less likely to choose government jobs compared to those with monthly family income at or below RM5,000. The marginal effects showed that respondents with monthly family income above RM5,000 have a $6.7 \%$ lower probability to choose government jobs compared to respondents with monthly family income at or below RM5,000. The results support the notion that people from lower income backgrounds are more likely to work for the government.

SecSch. The effect of type of secondary school attended by respondents was statistically significant and negatively related to the decision of choosing government jobs. The odds of choosing government jobs decreased by 0.698 times for respondents who did not attend SMK compared to those who did. The marginal effects indicated that respondents who did not attend SMK have a lower probability (4.5\%) to seek public employment compared to those who did. This finding seems to affirm the common belief in Malaysia whereby those who attended Chinese schools (i.e. did not attend SMK) are less likely to choose public sector careers compared to their counterparts.

MalayPro. The variable of Malay language proficiency was statistically significant and negatively related to the likelihood of choosing public employment. The odds of choosing public employment decreased by 1.946 times for respondents who have Good Proficiency in Malay compared to those who are not proficient in the language. The probability of respondents who have good proficiency in Malay choosing public employment decreased by $7.5 \%$ relative to those who are not proficient in the language. This result seems puzzling as the Malay language is 
the main language that is used in the government sector and obtaining a Grade $\mathrm{C}$ is one of the requirements to enter the Malaysian public sector. However, it was found that even though fulfilling this requirement, the group of respondents who are proficient in the Malay language is still less likely to choose government jobs compared to their counterparts. This probably is, again, related to the perception of discrimination treatment against minorities in the public sector.

In short, results of the logit model suggest that besides job characteristics (Attrctv), some personal characteristics (MalayPro), and background characteristics (Income and $\mathrm{SecSch}$ ) are significant in influencing respondents' choices and the model is deemed a good fit for enhancing prediction of the likelihood of respondents choosing public employment.

\section{CONCLUDING REMARKS AND PRACTICAL IMPLICATIONS}

The disconnection between students' life and launching a successful career and the perceived discrimination faced by minorities in public employment were not unique and do not solely occur in Malaysia. Therefore, even though the research was conducted in Malaysia, the findings of the study and hence its implications (discussed below) might be applicable in many countries that are facing a similar situation.

This study assessed determinants that influence private tertiary institution graduates in choosing their future career pathway of whether to work with the government sector. Findings revealed that job characteristics still stood out to be the vital motivator for choosing a career as evidenced by high ratings of the importance on the 10 job characteristics examined in the study and the significance of the index of attractiveness in the logit model. Overall, in terms of job characteristics attractiveness, public employment still appeared to be less attractive than private employment to private college graduates and the perception of discrimination against minority groups was prevalent among the study's respondents. Of all the job characteristics, pay not only ranks first in terms of importance of all job characteristics examined in the study (see Table 4), but it also tops the pull and push factors lists of chooser and non-chooser of public employment (see Tables 9 and 10). The results indicated the significance of pay in affecting one's career choice. Improving pay in the public sector or minimising the pay gap between public and private sectors probably will help increase the attractiveness of public employment.

Other than job characteristics, background characteristics such as family income and personal characteristics such as type of secondary school attended and Malay language proficiency are also significant variables that affect the likelihood of respondents in choosing government jobs. 
Two interesting findings of this study are worth highlighting. First, there were only $10.8 \%$ out of the 1,290 respondents who will consider government jobs. Second, logically when one perceived a job as attractive, $\mathrm{s} /$ he is more likely to choose the job instead of vice versa. This popular belief is supported by Woo's (2011 and 2017) studies. However, this study demonstrated contrary to that belief, whereby respondents of the study who rated public employment as High in attractiveness are less likely to consider public sector jobs than those who rated it as Low in attractiveness. This has probably something to do with the negative perceptions towards the public sector among respondents. The prevalence of discriminatory perception against minorities in the public sector among respondents probably partly explains these two interesting findings. As discussed earlier, perception guides behaviour. This negative perception alone is significant enough to make other factors secondary or not coming into operation. The increasingly mono-ethnic civil service together with this discriminatory perception probably have a "chilling effect", i.e. an effect where it tends to keep people from seeking employment and advancement in an organisation even in the absence of formal bars (Shafriftz et al. 2001) to minorities.

\section{Implications to Policymakers}

The first practical implication to be noted here is related to attracting more minorities to the public sector to promote social inclusiveness and the legitimacy of the government. In any modern democratic government, representation is necessary in relation to legitimacy and democracy. At the minimum, it is argued that the government administration should recognise the diversity of its society. Hence, having a representative bureaucracy is essential in modern democracies. Policymakers must realise the importance of having a representative bureaucracy. Studies demonstrated that a bureaucracy that captures most, if not all, aspects of its society's population in the governing body of the state would improve equitable responsiveness, social inclusiveness, civil service performance, and the legitimacy of a government, among others (Bradbury and Kellough 2011; Lim 2006; Meier and Nicholson-Crotty 2006; Selden 1997; Theobald and Haider-Markel 2009; Wilkins and Keiser 2001). Attracting more minorities to the public sector is the main way to improve the representativeness of the increasingly mono-ethnic bureaucracy. To enhance the attractiveness of public employment to minority groups, the utmost challenge that appears to the government is to rectify the negative discriminatory image against minorities. This issue needs to be addressed urgently to attract talents of minority groups. Policies of selection and recruitment into the public sector might be colour blind, however, human being factors count in the real process of selecting and recruiting public personnel. Having a more representative public personnel selection and recruitment team might help in this matter. 
Other measures like improving those job characteristics that is generally perceived as not so attractive such as representative/multiracial workplace, job satisfaction, image, promotion prospects, autonomy, and interesting and challenging job (as indicated in Table 5) are also relevant and important strategic actions that should be taken by public personnel managers or policymakers.

\section{Implications to Career Counsellors}

Findings of the study might better equip career counsellors in advising graduating students in relation to their future careers. While advising students in their career plans, apart from providing information that are offered by both private and public employment, some reality constraints (such as family socio-economic conditions, their personal ability, etc.) need to be highlighted to students so that they are more aware and prepared in making real choices in the real world after graduation. This is important in helping students to connect their dream job with the real career world and in launching a more practical career plan. Career counsellors might also call students' attention to opportunities they have in the public sector or clarify government recruitment policies (that are not against them) to students so that students will not unnecessarily shy away from public employment. This is to avoid misinformation and help to minimise the "chilling effect" that minorities might have due to their (wrong or negative) perceptions. It also might free students of minority groups who are considering government jobs from unnecessary worries and stress.

\section{Suggestions for Further Study}

Future work that aims to study the attractiveness of public employment and factors affecting career choice should cover more and ideally, all universities to enhance the generalisability of its findings. It should also include the investigation of how programmes of study or courses offered (by universities/colleges) affect graduates' decision in joining or avoiding public employment. This is important as judging from the nature of some courses (e.g., courses that prepare their students for business and industry related professions), this group of students may not be suitable for public sector careers and they themselves have probably already self-selected themselves into the private sector and have much less interest in public sector careers. Future studies should also study the attractiveness of public employment among non-graduate job seekers. Although non-graduate civil servants, the Support Group, fill lower-rank positions, they form the bulk of civil servants. Their capacity and representativeness are also important for improving the performance of the Malaysian civil service. 


\section{NOTES}

1. Generally, official statistics on racial breakdowns of the Malaysian civil service is conspicuously unavailable. This is the latest data which was released by a Minister in the Malaysian Prime Minister's Department on a question submitted by a Member of Parliament from the opposition party in a parliamentary sitting in 2015.

2. In Malaysia, a civil servant is defined as one who is working in the federal and state general public service, the joint public services, the education service, the judiciary and the legal service, and the armed forces as stipulated in Article 132 of the Constitution of Malaysia (The Commissioner of Law Revision 2010).

3. In Malaysia, data on public job applicants' educational background is rarely released to the public. This was the only data that was found in a published source.

4. Public service motivation or the desire to serve the public is a distinctive motive for preferring public employment because it offers more scope for this purpose. It is argued that people with strong public service motivation will be more attracted to public sector careers (Perry and Wise 1990).

\section{REFERENCES}

Abdullah Sanusi Ahmad, Norma Mansor and Abdul Kuddus Ahmad. 2003. The Malaysian bureaucracy: Four decades of development. Kuala Lumpur: Pearson Malaysia.

Administrative and Diplomatic Office (PTD). 2016. The story behind the scene. http://www.apistakkisah.com/2016/07/administrative-and-diplomatic-office.html (accessed 3 April 2018).

Alexander, P.M., M. Holmner, H.H. Lotriet, M.C. Matthee, H.V. Pieterse, S. Naidoo, H. Twinomurinzi and D. Jordaan. 2011. Factors affecting career choice: Comparison between students from computer and other disciplines. Journal of Science Education and Technology 20(3): 300-315. https://doi.org/10.1007/s10956-0109254-3

Blank, R.M. 1985. An analysis of workers' choice between employment in the public and private sectors. ILR Review 38(2): 211-224. https://doi.org/ 10.1177/001979398503800204

Bradbury, M. and E.J. Kellough. 2011. Representative, bureaucracy: Assessing the evidence on active representation. American Review of Public Administration 41(2): 157-167. https://doi.org/10.1177/0275074010367823

Chin, J. 2011. History and context of public administration in Malaysia. In Public administration in Southeast Asia: Thailand, Philippines, Malaysia, Hong Kong, and Macao, ed. E.M. Berman, 141-154. Boca Raton: CRC Press.

Christensen, R.K. and B.E. Wright. 2011. The effects of public service motivation on job choice decisions: Disentangling the contributions of person-organization fit and person-job fit. Journal Public Administration Research and Theory 21(4): 723-743. https://doi.org/10.1093/jopart/muq085 
Cohen, L., J. Duberley and M. Mallon. 2004. Social constructionism in the study of career: Accessing the parts that other approaches cannot reach. Journal of Vocational Behaviour 64(3): 407-422. https://doi.org/10.1016/j.jvb.2003.12.007

Creative Research Systems. 2017. The survey system. http://www.surveysystem.com/ sscalc.htm\#two (accessed 2 March 2017).

Daniel, A. and S. Encel. 1981. Public perception of the public administrator. Australian Journal of Public Administration XL(3): 187-200. https://doi. org/10.1111/j.1467-8500.1981.tb00505.x

Dugarova, E. and T. Lavers. 2015. Social inclusion and the post-2015 sustainable development agenda. Paper prepared for UNITAR's briefing for UN Delegates of Post-2015 Development Agenda: Social Inclusion. http://www.unrisd.org/ unitar-social-inclusion (accessed 2 March 2017).

Fertig, A. 2016. 4 misconceptions about getting a job after college. U.S.News, 20 January. http://money.usnews.com/money/blogs/outside-voices-careers/articles/2016-0120/4-misconceptions-about-getting-a-job-after-college?int=a96509 (accessed 25 January 2016).

FMT Reporters. 2015. Lack of non-Bumis in civil service must be addressed. FMT, 9 May. http://www.freemalaysiatoday.com/category/nation/2015/05/09/lack-of-nonbumi-in-civil-service-must-be-addressed/ (accessed 1 February 2017).

Gujarati, D. 2003. Basic econometrics. 4th ed. New York: The McGraw-Hill Companies.

Gupta, U.G. and L.E. Houtz. 2000. High school students' perceptions of information technology skills and careers. Journal of Industrial Technology 16(4): 2-8.

Hull, K.E. and R.L. Nelson. 2000. Assimilation, choice, or constraint? Testing theories of gender differences in the careers of lawyers. Social Forces 79(1): 229-264. https://doi.org/10.1093/sf/79.1.229

Index Mundi. 2016. Malaysia demographics profile 2016. http://www.indexmundi.com/ malaysia/demographics_profile.html (accessed 3 March 2017).

Kilpatrick, F.P., M.C. Cummings Jr. and M.K. Jennings. 1964. The image of the federal service. Washington, D.C.: The Brookings Institution.

Konrad, A.M., E. Corrigall, P. Lieb and J.E. Ritchie. 2000. Sex differences in job attribute preferences among managers and business students. Group \& Organizational Management 25(2): 108-131. https://doi.org/10.1177/1059601100252002

Lee, Y.L. and V.M. Wilkins. 2011. More similarities or more differences? Comparing public and nonprofit managers' job motivations. Public Administration Review 71(1): 45-56. https://doi.org/10.1111/j.1540-6210.2010.02305.x

Leitão, I.M., Á. Guedes, M.E. Yamamoto and F. de Araújo Lopes. 2013. Do people adjust career choices according to socioeconomic conditions? An evolutionary analysis of future discounting. Psychology and Neuroscience 6(3): 383-390. https://doi.org/10.3922/j.psns.2013.3.16

Lewis, G.B. and S.A. Frank. 2002. Who wants to work for the government? Public Administration Review 62(4): 396-404. https://doi.org/10.1111/0033-3352.00193

Lim, H.H. 2006. Representative bureaucracy: Rethinking substantive effects and active representation. Public Administration Review 66(2): 193-204. https://doi.org/ 10.1111/j.1540-6210.2006.00572.x 
2013. The public service ethnic restructuring under the New Economic Policy: The new challenge of correcting selectivity and excess. In The New Economic Policy in Malaysia: Affirmative action, ethnic inequalities and social justice, eds. E.T. Gomez and J. Saravanamuttu, 175-203. Singapore: NUS Press.

Lucas, R.E.B. and D. Verry. 1999. Restructuring the Malaysian economy: Development and human resources. New York: St. Martiu's Press. https://doi.org/10.1007/ 978-1-349-27451-2

McGraw, K., J.S. Popp, B.L. Dixon and D.J. Newton. 2012. Factors influencing job choice among agricultural economics professionals. Journal of Agriculture and Applied Economics 44(2): 251-265. https://doi.org/10.1017/S1074070800000304

Meier, K.J. and J. Nicholson-Crotty. 2006. Gender, representative bureaucracy, and law enforcement: The case of sexual assault. Public Administration Review 66(6): 850-860. https://doi.org/10.1111/j.1540-6210.2006.00653.x

Miles, J. and M. Shevlin. 2003. Applying regression and correlation: A guide for students and researcher. London: Sage Publications.

Perry, J.L. and L.R. Wise. 1990. The motivational bases of public service. Public Administration Review 50: 367-373. https://doi.org/10.2307/976618

Rettenmayer, J., R. Berry and S. Ellis. 2007. The image of the information system profession: An investigation of gender differences. Consortium for Computing Sciences in Colleges 22(5): 46-51.

Saupee. 2012. PTD the premier service and glamour civil servant/Pegawai Tadbir dan Diplomatik, 24 December. http://saupee.blogspot.my/2012/12/ptd-premierservice-and-glamour-civil.html (accessed 3 March 2017).

Selden, S.C. 1997. The promise of representative bureaucracy. Armonk, NY: M.E. Sharpe. Shafriftz, J.M., D.H. Rosenbloom, N.M. Riccucci, K.C. Naff and A.C. Hyde. 2001. Personnel management in government: Politics and process. New York, Basel: Marcel Dekker, Inc.

Shumba, A. and M. Naong. 2013. The influence of family income on students' career choice at universities of technology. South African Journal of Higher Education 27(4): 1021-1037.

Stahl, O.G. 1966. Public personnel administration. New Delhi: Oxford \& IBH Publishing.

Stritch, J.M. and R.K. Christensen. 2016. Raising the next generation of public servants? Parental influence on volunteering behaviour and public service career aspirations. International Journal of Manpower 37(5): 840-858. https://doi.org/10.1108/IJM12-2014-0249

Swinhoe, K. 1967. Factors affecting career choice among full-time students in a college of commerce. The Vocational Aspect of Education 19(43): 139-154. https://doi. org/10.1080/03057876780000161

Tang, M., N.A. Fouad and P.L. Smith. 1999. Asian Americans' career choices: A path model to examine factors influencing their career choices. Journal of Vocational Behaviour 54(1): 142-157. https://doi.org/10.1006/jvbe.1998.1651

Theobald, N.A. and D.P. Haider-Markel. 2009. Race, bureaucracy, and symbolic representation: Interactions between citizens and police. Journal of Public Administration Research and Theory 19(2): 409-426. https://doi.org/10.1093/ jopart/mun006 
The Commissioner of Law Revision, Malaysia. 2010. Federal Constitution (reprint). Kuala Lumpur: Percetakan Nasional Malaysia Berhad.

Tolbert, P.S. and P. Moen. 1998. Men's and women's definitions of "good" jobs: Similarities and differences by age and across time. http://digitalcommons.ilr. cornell.edu/articles/436b (accessed 23 March 2018).

Vroom, V.H. 1967. Work and motivation. New York: John Willey \& Sons, Inc.

Walstrom, K.A., T.P. Schambach, K.T. Jones and W.J. Crampton. 2008. Why are students not majoring in Information Systems? Journal of Information Systems Education 19(1): 43-54.

Wan, C.D. 2007. Public and private higher education institutions in Malaysia: Competing, complementary or crossbreed as education providers. Kajian Malaysia 25(1): $1-14$.

Wilkins, V.M. and L.R. Keiser. 2001. Linking passive and active representation for gender: The case of child support agencies. Paper presented at the Sixth National Public Management Conference, Bloomington, Indiana, USA, 18-20 October.

Woo, K.H. 2011. The attractiveness of public employment: A study of perception among final year university students in Peninsular Malaysia. PhD diss., School of Social Sciences, Universiti Sains Malaysia.

2015. Recruitment practices in the Malaysian public sector: Innovations or political responses? Journal of Public Affairs Education 21(2): 229-246. https://doi.org/10.1080/15236803.2015.12001830

2017. Public employment: Attractiveness, representativeness, and performance. International Journal of Public Administration 41(8): 604-618. https://doi.org/ 10.1080/01900692.2017.1292284 